\title{
DEVELOPMENT OF VOCATIONAL MATERIAL LEARNING MEDIA FOR MATERIAL X CLASS
}

\author{
Atik Restyowati 1), Dian Puspita Anggraini 2), Eva Nurul M ${ }^{3}$ ) \\ ${ }^{1,2}$ Islamic University of Balitar; Jl. Majapahit No.04, Telp. (0342) 813145 \\ 3 Jurusan Pendidikan Biologi, FKIP Universitas Islam Balitar, Blitar \\ E-mail: ${ }^{* 1}$ atik @gmail.com ${ }^{2}$ dianpuspitaanggraini@unisbablitar.ac.id, \\ evanurul@unisbablitar.ac.id
}

\begin{abstract}
This study aims to determine the three-dimensional media feasibility of virus material in class $x$. This type of research is Research and Development ( $R$ \& $D)$ with the development model Brog \& Gall. This research through assessment by media experts with an average score of $74.87 \%$ with a very feasible category. The research from material experts got an average score of $93.5 \%$ with a very decent category. Assessment of teacher responses gets a score of $82.10 \%$ with a very decent category. Assessment of student responses is $80.46 \%$ with a very good category. Readability test scores get a score of $89.2 \%$ with a decent category. Media maket on viral material is very feasible to use for learning in the classroom.
\end{abstract}

Keywords: Research Development, Model, Virus

\section{INTRODUCTION}

Education plays a very important role and factors in human life because it is one vehicle for creating quality human resources. The importance of education for humans is stated in Law Number 20 of 2003 that education is a conscious and planned effort to realize the learning atmosphere and the process of learning actively actively developing its potential.

Changes in the curriculum from the Education Unit Level Curriculum (KTSP) to the 2013 Curriculum (K13) bring changes to the four aspects of change, among others, changes in student competency standards, content standards, process standards and assessment standards. Changes according to the achievement of student learning competencies not only on the aspects of knowledge but also emphasize the achievement of students' skills and attitudes.

Based on observations in the field through interviews and giving questionnaires to students and teachers shows that biology learning in the 
virus material in the school is the teacher using worksheets, examples of images, charts and video views using LCD. The teacher has been helped by the media, but there are still students who do not understand virus material because viral material is abstract material that requires high imagination. Biology teachers need learning media that can facilitate students to learn Biology material. As well as researchers can develop learning media maket in Biology learning class $X$ with the hope that the media is feasible to be used specifically on viral material, so that it can help students to develop ways of thinking by reproducing real forms and illustrations to facilitate students in learning viral material.

Learning media is a set of tools that are used by teachers or educators in order to communicate with students or students. Materials packaged through media programs will be clearer, more complete, and interesting for students. Learning media are also able to present material that can arouse students' curiosity, stimulate students to react physically and emotionally (Widyastuti and Nurhidayati, 2010).

One of the media that can provide a direct description of the viral material is a three-dimensional media, one of which is media maket. Mockup media is a copy of something in small size. Media mockups can attract students' attention, because they lay concrete foundations. Makets are classified into three-dimensional visual media, namely a form of miniature models made from designs designed or to be built.

Mockups have a shape made in three dimensions like the original (in miniature form), coupled with realistic color rendering and giving shadows that are used to direct attention and distinguish components can provide an attractive impression for anyone who sees, gives experience directly, presenting concrete material that is not pherbalistic. Therefore, it is expected to be able to improve students' memory of learning information contained in the media. 
Some studies on Macet media development have been conducted by Meylasari (2012), Graniy Noval (2016) and Novia (2017) media maket in learning with good results and media feasibility by several validators which have very good results so that learning media models are feasible in use in the learning process.

\section{RESEARCH METHODS}

The approach used in this study is quantitative and qualitative approaches. Quantitative data in the form of assessment scores from expert teams. Qualitative data in the form of advice and input from the expert team. The research design used is Research and Development $(R$ \& D) with the development model Brog \& Gall which consists of stages (1) potential and problems; (2) data collection; (3) product design; (4) design validation; (5) design revisions; (6) product testing; (7) product revisions; (8) trial use; (9) product revisions; and (10) production. (Sugiyono 2013: 298). But in this study researchers only limited to 5 stages.

The research procedure starts from the potential stage and the problem of the data collection stage, product design stage, design validation stage, design revision stage, product trial and product revision. The potential stage of the problem is done to find out the problems that occur in the classroom developed through front end analysis, student analysis, task analysis, concept analysis and formulating objectives. The data collection stage collects the data that has been obtained from teacher and student interviews that are done, namely compiling tests, selecting media, choosing the format and preparing the initial design of the product. The design validation stage is a process to produce a product that is feasible to use through validation by a team of experts

Product specifications The initial design of the product is made to design the media by collecting tools and materials needed. The tools and materials used are scissors, paperboard, paint, sterophones, sandpaper, 
JOSAR, Vol. 1 No. 1 March, 2018; p-ISSN: 2502-8251; e-ISSN: 2503-1155

Copyrights@ Balitar Islamic University, Blitar-Indonesia

https://ejournal.unisbablitar.ac.id/index.php/josar

glue, pears, acrylic, ordinary paperboard to make parts of the virus head, used to make lytic and lysogenic spherical and viral viruses, and glue to attach each strofom which is already in the form of an empty cardboard is used to form a circle on the neck of the virus, pears are used to make the virus stem and the body of the virus. Then make the initial design of the model, by determining the theme and material to be used. Making the design of media content models based on the material and indicators that have been made and designed The material included is taken from various sources both books, journals and from the internet whose sources are clear and accountable.

After the material is collected, it is then cut into wood, paperboard according to the size specified for the maket media. Determine designation on commercial media related to viral material. Search for image images in each media so that students are easily understood. Then proceed with giving interesting colors on wood and paperboard so the participants can see and understand. The products produced are in the table $\mathbf{3 . 1 1}$

\begin{tabular}{ll}
\hline Persentase & \multicolumn{1}{c}{ Kategori } \\
\hline $0 \%-20 \%$ & $\begin{array}{l}\text { Sangat } \\
\text { Layak }\end{array}$ \\
\hline $20 \%-40 \%$ & Tidak \\
\hline $40 \%-60 \%$ & Cukup Layak \\
\hline $60 \%-80 \%$ & Layak \\
\hline $80 \%-100 \%$ & Sangat Layak \\
\hline
\end{tabular}

( Sumber : diadaptasi dari Sugiyono, 2011) 
JOSAR, Vol. 1 No. 1 March, 2018; p-ISSN: 2502-8251; e-ISSN: 2503-1155

Copyrights@ Balitar Islamic University, Blitar-Indonesia

https://ejournal.unisbablitar.ac.id/index.php/josar

Table 3.12 Validity Level Criteria

\begin{tabular}{lll}
\hline $\begin{array}{l}\text { Presentase } \\
\text { (dalam persen) }\end{array}$ & $\begin{array}{l}\text { Tingkat } \\
\text { Kevalitan }\end{array}$ & Keterangan \\
\hline $80-100$ & Valid & Sangat layak \\
$60-70$ & Cukup Valid & Layak \\
$40-59$ & Kurang Valid & Kurang layak \\
$0-39$ & Tidak Valid & Tidak layak \\
\hline \multicolumn{2}{c}{ (sumber:diadatasi dari Jannah, 2013) }
\end{tabular}

\section{RESULTS AND DISCUSSION}

The development of the three-dimensional cross-sectional media of the stem of the Angiospermae plant was validated by material experts, media experts and linguists. The results of expert validation are shown in Tables 3, 4 and 5. The results of teacher evaluations and student responses are shown in Tables 6 and 7.

Table 4.1 Results of Media Evaluation of Materials by Materials Media Expert Validation Results

liMateri

\begin{tabular}{rrrrr}
\hline $\begin{array}{l}\text { PERTANYAAN } \\
\text { KE }\end{array}$ & & & & \\
& AHLI 1 & AHLI 2 & AHLI 3 & \multicolumn{2}{c}{ TOTAL SKOR } \\
\hline 1 & 5 & 5 & 4 & 14 \\
\hline 2 & 5 & 5 & 5 & 15 \\
\hline 3 & 5 & 5 & 5 & 15 \\
\hline 4 & 4 & 5 & 5 & 14 \\
\hline 5 & 5 & 5 & 5 & 15 \\
\hline 6 & 5 & 5 & 4 & 14 \\
\hline 7 & 4 & 4 & 5 & 13 \\
\hline 8 & 5 & 5 & 4 & 14 \\
\hline 9 & 5 & 5 & 5 & 15 \\
\hline 10 & 4 & 5 & 5 & 14 \\
\hline & & & & 46
\end{tabular}


JOSAR, Vol. 1 No. 1 March, 2018; p-ISSN: 2502-8251; e-ISSN: 2503-1155

Copyrights@ Balitar Islamic University, Blitar-Indonesia

https://ejournal.unisbablitar.ac.id/index.php/josar

\begin{tabular}{|c|c|c|c|c|}
\hline Jumlah & 47 & 49 & 47 & 143 \\
\hline & & & & 150 \\
\hline
\end{tabular}

a. Student Readability Test

b. Results of response analysis students This data is used to determine student responses to the media being developed

\begin{tabular}{lrrrrr}
\hline $\begin{array}{l}\text { PERTANYAAN } \\
\text { KE }\end{array}$ & & & & \\
& AHLI 1 & AHLI 2 & AHLI 3 & \multicolumn{2}{l}{ TOTAL SKOR } \\
\hline & 1 & 3 & 4 & 5 & 12 \\
\hline & 2 & 4 & 3 & 3 & 10 \\
\hline & 3 & 4 & 4 & 4 & 12 \\
\hline & 4 & 3 & 4 & 4 & 11 \\
\hline & 5 & 4 & 4 & 3 & 11 \\
\hline & 6 & 4 & 4 & 4 & 12 \\
\hline & 7 & 3 & 4 & 4 & 11 \\
\hline & 8 & 3 & 4 & 4 & 11 \\
\hline & 10 & 3 & 4 & 4 & 10 \\
\hline & 11 & 3 & 4 & 3 & 11 \\
\hline jumlah & 12 & 3 & 4 & 4 & 10 \\
\hline Skor & 13 & 4 & 4 & 5 & 13 \\
\hline presentase & & 44 & 50 & 51 & 145 \\
\hline
\end{tabular}

a. trial readability

\begin{tabular}{ccccccc}
\hline PERTANYAA & \multicolumn{4}{c}{ PENILAIAN } & & \multicolumn{2}{c}{$\begin{array}{c}\text { JUMLAH } \\
\text { SKOR }\end{array}$} \\
\cline { 2 - 7 }$N$ & 1 & 2 & 3 & 4 & 5 & \\
\hline
\end{tabular}


JOSAR, Vol. 1 No. 1 March, 2018; p-ISSN: 2502-8251; e-ISSN: 2503-1155

Copyrights@ Balitar Islamic University, Blitar-Indonesia

https://ejournal.unisbablitar.ac.id/index.php/josar

\begin{tabular}{lrrrrrrr}
\hline & 1 & 5 & 5 & 5 & 4 & 5 & 24 \\
\hline & 2 & 4 & 4 & 4 & 5 & 4 & 21 \\
\hline & 3 & 4 & 5 & 5 & 4 & 5 & 23 \\
\hline & 4 & 5 & 4 & 4 & 5 & 4 & 22 \\
\hline & 5 & 4 & 5 & 5 & 4 & 5 & 23 \\
\hline 6 & 5 & 4 & 4 & 5 & 4 & 22 \\
\hline & 7 & 5 & 4 & 5 & 4 & 5 & 23 \\
\hline & 8 & 4 & 4 & 4 & 5 & 4 & 21 \\
\hline & 9 & 5 & 5 & 5 & 4 & 5 & 24 \\
\hline & 10 & 5 & 4 & 4 & 5 & 4 & 22 \\
\hline & 11 & 4 & 5 & 4 & 4 & 4 & 21 \\
\hline JUMLAH & 12 & 5 & 4 & 5 & 5 & 5 & 24 \\
SKOR & 4 & 4 & 4 & 4 & 4 & 20 \\
\hline \multirow{2}{*}{ SKOR } & & 59 & 57 & 58 & 58 & 58 & 290 \\
\hline presentase & & & & & & & \\
\hline
\end{tabular}

. a. Results of response analysis students

This data is used to determine student responses to the media being developed

\begin{tabular}{rrr}
\hline NO & SOAL & JUMLAH \\
\hline 1 & 1 & 151 \\
\hline 2 & 2 & 132 \\
\hline 3 & 3 & 146 \\
\hline 4 & 4 & 126 \\
\hline 5 & 5 & 132 \\
\hline 6 & 6 & 138 \\
\hline 7 & 7 & 137 \\
\hline 8 & 8 & 134 \\
\hline 9 & 9 & 136 \\
\hline 10 & 10 & 135 \\
\hline 11 & 11 & 131 \\
\hline 12 & 12 & 139 \\
\hline 13 & 13 & 145 \\
\hline 14 & 14 & 133 \\
\hline JUMLAH & 1915 \\
\hline SKOR & 2380 \\
\hline PRESENTASE & $80,46 \%$ \\
\hline
\end{tabular}


JOSAR, Vol. 1 No. 1 March, 2018; p-ISSN: 2502-8251; e-ISSN: 2503-1155

Copyrights@ Balitar Islamic University, Blitar-Indonesia

https://ejournal.unisbablitar.ac.id/index.php/josar

a. a. Teacher response analysis

This data is used to determine student responses to the media being developed

\begin{tabular}{lrrrr}
\hline $\begin{array}{l}\text { PERTANYAAN } \\
\text { KE }\end{array}$ & & & & \\
\hline & 1 & 5 & 4 & \\
\hline & 2 & 5 & 4 & 9 \\
\hline 3 & 5 & 4 & 9 \\
\hline 4 & 4 & 4 & 8 \\
\hline 5 & 5 & 3 & 8 \\
\hline 6 & 5 & 3 & 8 \\
\hline 7 & 4 & 4 & 8 \\
\hline 8 & 4 & 4 & 8 \\
\hline 9 & 4 & 4 & 8 \\
\hline & 10 & 4 & 4 & 8 \\
\hline 11 & 5 & 4 & 9 \\
\hline & 12 & 4 & 4 & 8 \\
\hline 13 & 4 & 4 & 8 \\
\hline & 14 & 5 & 4 & 9 \\
\hline 15 & 4 & 4 & 8 \\
\hline & 16 & 4 & 3 & 7 \\
\hline & 17 & 4 & 3 & 7 \\
\hline & 18 & 5 & 4 & 9 \\
\hline jumlah & 19 & 4 & 4 & 156 \\
\hline skor & & 84 & 72 & 190 \\
\hline presentase & & & & \\
\hline
\end{tabular}

Based on the results of the study through assessment by media experts with an average score of $74.87 \%$ with a very feasible category. The research from material experts got an average score of $93.5 \%$ with a very decent category. Assessment of teacher responses gets a score of $82.10 \%$ with a very decent category. Assessment of student responses is $80.46 \%$ with a very good category. Readability test scores get a score of $89.2 \%$ with a decent category. Media maket on viral material is very feasible to use for learning in the classroom. 
This research was also conducted by Meylasari (2012) to improve student learning outcomes in science subjects. Based on the results of the implementation of the action, reflection on the development of science learning in the implementation of learning using media maket students experienced an increase in learning. Graniy Noval (2016) 3D Macet learning media obtained a percentage value of $80.96 \%$, with details of the value of Media Experts at $85 \%$ and from Material Experts at $76.92 \%$. Based on the Likert scale the number $80.96 \%$ is included in the range of $80.01 \%-100.00 \%$ so that it is included in the criteria of "Very Worthy". Novia (2017) the model of learning in biology learning produces effective learning media to be applied to biology learning.

\section{CONCLUSION}

Learning media mockup learning media that are feasible to use this can be known from the results of the media and material validator scores getting a score of $81.27 \%$ while the responses of teachers and students get a score of $81.28 \%$ from the results obtained by highly feasible learning media to be used in learning.

\section{SUGGESTION}

Based on the research that has been carried out, researchers can provide advice related to problems related to problems related to research. The suggestions are as follows.

1. Further research is needed on the learning media maket on class $X$ virus material to be tested for the effectiveness of learning maket media on virus material for class $\mathrm{X}$ high school.

2. It is necessary to develop media learning models on other materials. 
JOSAR, Vol. 1 No. 1 March, 2018; p-ISSN: 2502-8251; e-ISSN: 2503-1155

Copyrights@ Balitar Islamic University, Blitar-Indonesia

https://ejournal.unisbablitar.ac.id/index.php/josar

\section{REFERENCES}

Arifin, zaenal.2014.Penelitian Pendidikan. Bandung: PT Remaja Rosdakarya.

Arifin, zaenal.2009. Evaluasi Pendidikan. Bandung: PT Remaja Rosdakarya.

Arikunto,dkk.2011. Dasar-Dasar Evaluasi. Jakarta: Bumi Aksara.

Arsyad, 2003. Media pembelajaran. Jakarta:PT Raja Grafindo.

Daryanto, 2012. Media Pembelajaran. Bandung: Sarana Tutorial Nurani Sejahtera

Sudjana N,Rivai A. 2013. Media Pengajaran. Bandung: Sinar Baru Algensindo.

Sugiyono. 2016. Metode Penelitian. Bandung: Alfabeta. 